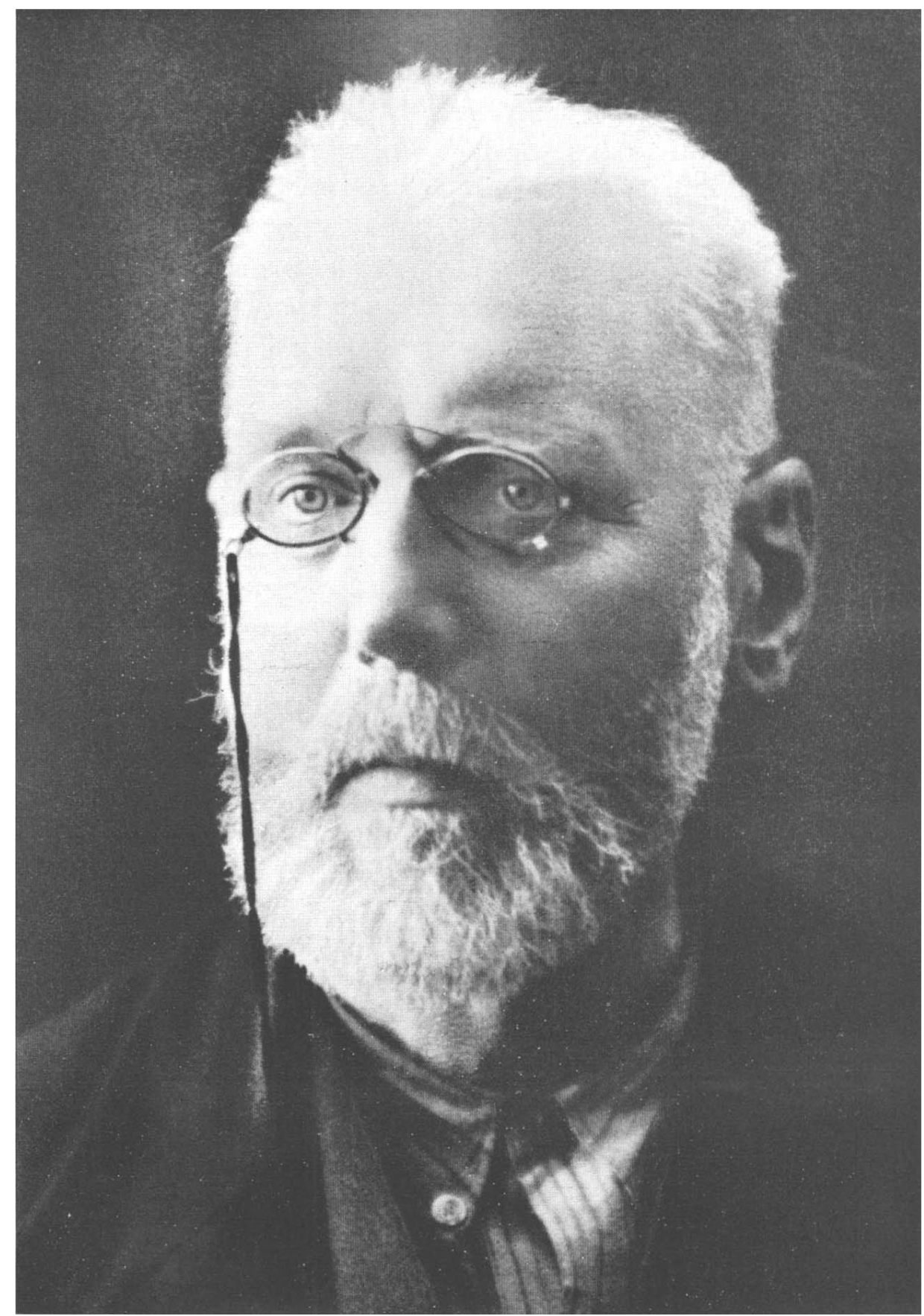

MAX NETTLAU 


\section{MAX NETTLAU}

Nettlau left Vienna after the Nazi occupation and came to Amsterdam, where he worked at the International Institute of Social History until the Germans closed the Institute in July 1940. He died at Amsterdam on July 23, 1944.

Max Nettlau was born on April 30, 1865, at Neuwaldegg, near Vienna. He studied philology at various German universities and specialised in the study of the grammar of the Indo-Germanic languages, especially Celtic and Cymric. In 1887 he received his doctors degree in philosophy at Leipzig University for his thesis' Beiträge zur cymrischen Gramma$t i k$. He worked in the British Museum and the Bodleian Library on his linguistic studies. When he arrived in London for the first time in the autumn of 1885 , he joined the Socialist League which had been founded a few months earlier and remained a member as long as it existed. In London he met many international socialists such as Victor Dave, Andreas Scheu, Peukert, Friedrich Lessner, the friend of Marx and former member of the Communist League, Eleonore AvelingMarx, Russians such as Burzev and Tcherkesov, many exiled Frenchmen and old French socialists of 1848 such as Jeanne Déroin. He saw many international socialist papers received in exchange for the Commontealth in the offices of the Socialist League. All this aroused his historical interest. In this milieu he heard of Ernest Coeurderoy and Joseph Déjacque, the early French anarchists, whose story he brought to life. In his first historical article published in Johann Most's Freiheit in New York (1890) he wrote about Déjacque. He followed this up with an article on the development of the anarchist ideas (Freiheit, April-May 1890), also issued as a pamphlet by Most and a biography on Bakunin (Freiheit, JanuaryApril 1891). These articles attracted great interest of men like Kropotkin, Reclus and Malatesta, all of whom gave him help and advice in his further historical investigations.

Although Nettlau continued his linguistic studies for some 
years he occupied himself mainly with the history of socialism and after 1890 concentrated his interest on a biography of Bakunin. Kropotkin, whom he met in London for the first time in 1888, introduced him to his old companions of the First International in Switzerland. In 1892 and 1893 Nettlau visited the surviving members of the Jura Federation and friends of Bakunin such as Adhémar Schwitzguébel, Louis Pindy, N. Joukovski, Jacques Gross, Professor Adolf Vogt, Charles Perron, Adolph Reichel and many others. $\mathrm{He}$ also went to Bucharest to see Z. Abore (known as Ralli), who was closely connected with Bakunin in the years 18721873 in Zürich. Subsequently he visited everybody still alive who had personally known Bakunin and thereby collected a mass of material for his biography. This famous work, $M i$ chael Bakunin. Eine Bibliographie was published in London 1896-1900 in three volumes of 1,283 folio pages, each of which was written on "wax paper" and duplicated on an "autocopist". The whole work was done by Nettlau himself and about 40 copies of it were sent to his personal friends and to libraries. In 1899 he continued his Bakunin studies in Italy. He saw Celso Cerretti and F. S. Merlino and Bakunin's family in Naples, from whom he received Bakunin's posthumous papers. Most of this material was summarised in his supplementary volumes (manuscript) (1903-1905), which James Guillaume used for his great work on the First International, L'Internationale. Documents et Souvenirs (Paris, 1905-1910). The manuscripts he had gathered enabled him to publish the first volume of Bakunin's Oeuvres (Paris, 1895). For a Spanish edition of Bakunin's works (Obras completas, 5 vols), published in Buenos Aires 1925-1929, Nettlau wrote long and important prefaces and he annotated the German edition (Werke Berlin, vol. 2 and 3, 1923-1924). Bakunin's activities in Italy were dealt with in the Italian book Bakunin e l'Internazionale in Italia. Dal 1864 al 1872, Con prefazione di Errico Malatesta (Geneva, 1928). Three studies dealing with Bakunin's connections with Spain, Italy and Russia appeared in Grüberg's Archiv für die Geschichte des Sozialismus und der Arbeiterbewegung (1912, 1913, 
1915). All the material on Spain was published in the two Spanish books Miguel Bakunin, la Internacional y la Alianza en España 1868-1873 (Buenos Aires, 1925) and Documentos ineditos sobre la Internacional y la Alianza en España (Buenos Aires, 1930). He wrote many articles about Bakunin's "Confession" of 1851, published in 1921 and he annotated the French edition (Michel Bakounine, Confession, Paris, 1932).

Of his other works we mention here only the unpublished biography of Coeurderoy, part of which was used for the introduction of his edition of Coeurderoy's Jour's d'Exil (Paris, 1910-1911, 3 vols) and for a summary published in Grünberg's Archiv (1911). During the twenties the publishing firm of the German syndicalists, following a suggestion of Rudolf Rocker, started to publish Nettlau's great historical works. By the time Hitler came to power three volumes on the history of the anarchist ideas had been published: $D e r$. Vorfrühling der Anarchie. Ihre historische Entwicklung von den Anfängen bis zum Jahre 1864 (1925); Der Anarchismus von Proudhon zu Kropotkin. Seine historische Entwicklung in den Jahren 1859-1880 (1927). Anarchisten und Sozialrevolutionäre. Die historische Entwicklung des Anarchismus in den Jahrèn 1880-1886 (1931). In addition to these three works, which brought the story of anarchism up to 1886 , Nettlau wrote the biographies of Elisée Reclus and Malatesta (Errico Malatesta. Das Leben eines Anarchisten. Berlin, 1922; Elisée Reclus. Anarchist und Gelehrter. 1830-1905 Berlin, 1928. Also Spanish and Italian editions).

For many years he was a regular contributor to Freedom and Les Temps Nouveaux and indeed to nearly all international anarchist periodicals. In later years many of his historical and theoretical articles were regularly published by $L a$ Protesta (Suplemento), Buenos Aires, La Revista Blanca, Barcelona, and Die Internationale Berlin. The whole of this Bulletin would be needed to list the innumerable articles he wrote, but we intend to publish a complete bibliography of his writings. His style is lengthy and cumbersome; his books, 
crowded with titles, notes and dates, are difficult to read and they sometimes give more the impression of bibliographies raisonnées rather than historical surveys.

Thanks to his independent means, his extraordinary knowledge of languages, his personal and friendly relations with all the leading anarchists of his time and with his sense for collecting, he was able to build up his famous and unique anarchist library. By 1888 he had started systematically to collect international anarchist literature and he continued to add to his collection for half a century. Apart from large files of rare papers, thousands of pamphlets, posters, handbils and similar rare material, hundreds of letters of historical interest, his collection includes the Bakunin papers and other documents pertaining to the "Bakunist International"; also archives such as that of Pierre Vésinier (1824-1902), which are of great importance for the history of the French proscription (1850-1860) and the First International. In 1936 the International Institute of Social History in Amsterdam acquired his library, the importance of which was increased by the acquisition of other anarchist libraries like that of Pierre Ramus, Auguste Hamon and others. A catalogue of the collection would be the greatest single contribution to a complete bibliography of anarchist literature, of which Nettlau himself gave the first outline in his Bibliographie de l'Anarchie (Paris, 1897), containing 4.000 titles.

After the First World War, his fortune vanished through the inflation and he could no longer make his annual trips to Switzerland, France and England. He lived under rather appalling conditions in Vienna in a small room in the Lazarettgasse; the room looked more like a storehouse for literature than a living room, which in any case he hardly ever left. He continued to receive there publications from all over the world.

Nettlau was personally of a kind nature. He had no social contacts, no personal needs and no relaxations. Day in, day out, he wrote articles and books and his long letters so well known to his friends and comrades in many countries. Rarely was a life more devoted to one purpose and a scholarly cause, 
with such singlemindedness and steadfastness, with such patience and complete disinterestedness. Only where authority was rejected did he discover freedom, humanity and progress. From this point of view and with an astounding knowledge of facts he wrote the history of socialism; indeed from this angle he regarded the whole development of mankind. Thus he wished to make his own contribution to the story of liberty. His works and collections are a permanent and monumental source for the history of anti-authoritarian thought and libertarian socialism.

A. L. 